\title{
Evaluation of Country Bean Germplasm Collected from Patuakhali Region
}

\author{
M. Ratna ${ }^{a}$, Md. Abdul Kayum ${ }^{\mathrm{b}}$ and Mohammad Zulficar Alic* \\ aAARI, Lebukhali Station, Patuakhali, \\ bDepartment of Agricultural Botany, Patuakhali Science \& Technology University, \\ cDepartment of Statistics, Patuakhali Science \& Technology University \\ *Corresponding author email: zulficar_bd@yahoo.com
}

\section{Doi: $10.2478 / m j h r-2021-0010$}

\begin{abstract}
:
The experiment was conducted at Regional Horticulture Research Station, Lebukhali, Patuakhali and were evaluated the genotypic performance like yield and yield traits of seventeen (17) country bean genotypes collected from Patuakhali region. In this area, country bean yield is very low, that why we need to identify high yielding country bean genotypes in Patuakhali region. The experiment was laid out in an augmented block design. Seventeen country bean lines viz., LPPK001 to LPPK017 and four check variety viz., BARI Sheem-1, 6, 7 and IPSA Sheem-2 were used for this trial. A lot of variability was observed such as plant height, pod length, pod breadth, pod weight, No. of pod plant ${ }^{-1}$, yield plant ${ }^{-1}, 100$ seed weight and yield. The pod length ranged from $20.4-7.62 \mathrm{~cm}$, pod breadth range from $4.83-1.41 \mathrm{~cm}$ and pod weight ranged from 13.28-5.08g. The longest pod (20.4 $\mathrm{cm})$, maximum pod breadth $(4.83 \mathrm{~cm})$ and the premier pod weight $(13.28 \mathrm{gm})$ were found in BARI Sheem 6, LPPK012 and LPPK002 respectively. The highest yield (18.73 t/ha) obtained from the line LPPK016 and minimum in the line LPPK 003 (5.43 t/ha). Among the 17 tested lines and 4 checks; 15 were green in colour, and IPSA Sheem 2 was light green, LPPK011 was purple green and LPPK001 and LPPK014 were creamy- white in colour. The wide variations in phenotypic level among the genotypes LPPK001, LPPK005, LPPK015, LPPK016, and BARI Sheem 7 can be potentially used for more production in Patuakhali region, ultimately it will increase the farmers' incomes level.
\end{abstract}

Keywords: Patuakhali, Production, Evaluation, Hyacinth Bean and Data Analysis

\subsection{Introduction}

Hyacinth bean (Lablab purpureus L.), also known as country bean, lablab bean or Indian bean, is one of the important legume vegetables of Bangladesh and grown throughout the country. Its cultivation and use are wide in winter season and it is almost impossible to find a homestead in rural Bangladesh without a vine of hyacinth bean [1]. It is known for edible young pods, dried seeds, leaves and flowers and it also produces green manure [2]. The crop has also been used as garden plant in USA for generations due to its beautiful dark green purple veined foliage with large spikes clustered with deep violet and white pea like blossoms. The beans are naturally rich in carbohydrates, proteins, fat and fibers as well as minerals including calcium, phosphorus and iron [3]. Among the legumes, hyacinth bean constitutes an important source of therapeutic agents used in the modern as well as traditional systems of medicine [4]. There are various types of hyacinth bean grown in different part of Bangladesh with various popular local name such as suri, puti, beta, noldog etc. Significant physico-morphological variation was found among the lines grown in Bangladesh [5]. This variation is a useful material to plant breeders for crop improvement. Characterization and evaluation will provide a rapid, reliable and efficient means of information for proper utilization of germplasm. This is also helpful to select suitable parental line for further improvement programme [6]. Information regarding the performances of the hyacinth bean cultivars is scanty under Patuakhali condition. Therefore, the present study was undertaken to evaluate the performance of hyacinth bean genotypes collected from this region and to get desirable lines for cultivation as well as for breeding purpose.

\subsection{Materials and methods}

The experiment was conducted during rabi season of 2017-18 at Regional Horticulture Research Station, Lebukhali, Patuakhali to evaluate the performances of seventeen (17) hyacinth bean lines in Patuakhali region. Seventeen lines viz., LPPK001 to LPPK017 and four check variety viz., BARI Sheem-1, BARI Sheem-6, BARI Sheem-7 and IPSA Sheem-2 were used for this trial. The experiment was laid out in augmented block design. Four plants were cultivated in each plot maintaining $2 \mathrm{~m}$ x $1.5 \mathrm{~m}$ spacing. Two seeds of each line were sown in polyethylene bag for seedling production on 11 September, 2017 and one seedling was removed from the polyethylene bag to keep healthy one after seed germination. Seedlings of 14 days old were transplanted in the pit on 24 September, 2017. The land was fertilized with Cowdung-10 t/ha, $\mathrm{N}_{28}, \mathrm{P}_{40}$ and $\mathrm{K}_{75}$ and $\mathrm{S}_{20} \mathrm{~kg} / \mathrm{ha}$ respectively. Half quantity of cowdung was applied during final land preparation. The remaining half quantity of cow dung, entire amount of $\mathrm{P}$ and half of $\mathrm{N}$ and $\mathrm{K}$ were applied during pit preparation. The remaining $\mathrm{N}$ and $\mathrm{K}$ were applied as topdressing at 30 days after transplanting. The plants were allowed to grow on trellis. Five weeding were done at 25, 40,60, 80 and 100 DAP. The crop was protected from the attack of pests; mainly aphids and pod borer by regular spraying of Chita @ $2 \mathrm{ml} / \mathrm{L}$. Data on plant height at 60 days (cm), primary branches per plant, days to $1^{\text {st }}$ harvest, number of pods per plant, single pod weight, 100 seed weight, pod yield per plant (kg), pod yield ( $\mathrm{t} / \mathrm{ha}$ ) were recorded. Data were analyzed statistically using ' $\mathrm{R}$ ' version 3.4.4 software.

\subsection{Results and Discussions}

Performance of seventeen hyacinth bean lines with check variety on yield and yield contributing characters are presented in Table 1 . The adjusted treatment effects were significant for all of the traits. However, the adjusted block effects were non-significant for all traits except pod yield per plant and yield (t/ha) indicating homogeneity of evaluation blocks. Among the lines, highest plant height was observed in LPPK012 (395.25 cm) which was identical to LPPK015 $(364 \mathrm{~cm})$ and LPPK005 $(327.75 \mathrm{~cm})$. On the other hand, lowest plant height was observed in LPPK002 $(205.25 \mathrm{~cm})$ which was statistically similar to LPPK011 $(217.75 \mathrm{~cm})$ and IPSA Sheem $2(237 \mathrm{~cm})$. Among the lines, plant showed significance height differences due to its genetical characters. Maximum number of branches was noticed in LPPK 015 (9.13) which was statistically similar to LPPK007 (8.56) and LPPK002 (8.26) where as minimum number of branches was noticed in LPPK005 (3.56). Days to first harvest were earlier in BARI Sheem7 (68.8 days) followed by BARI Sheem 1 (98.6days). On the contrary, days to first harvest were delayed in LPPK005 (140.35 Days) and LPPK009 (140.85 days). Days to first harvest is very important for the farmers due to its market value. The longest pod $(20.4 \mathrm{~cm})$ was found in BARI Sheem 6 followed by LPPK014 $(15.67$ $\mathrm{cm})$, LPPK001 $(15.14 \mathrm{~cm})$ and LPPK012 $(15.07 \mathrm{~cm})$ and the line LPPK007 produced the shortest pod $(7.62 \mathrm{~cm})$ which was statistically similar to LPPK004 $(8.74 \mathrm{~cm})$, LPPK008 $(8.47 \mathrm{~cm})$ and IPSA Sheem $2(8.4 \mathrm{~cm})$ respectively. Maximum pod breadth was observed in LPPK012 (4.83 cm) followed by 
LPPK002 $(4.21 \mathrm{~cm})$ and LPPK010 $(3.96 \mathrm{~cm})$ whereas minimum pod breadth wad noticed in LPPK004 $(1.41 \mathrm{~cm})$ which was identical to LPPK008 (1.51 $\mathrm{cm})$ and LPPK016 $(1.58 \mathrm{~cm})$ respectively. Variation in pod length was similar to Islam (2010) who reported variation on it from $3.96 \mathrm{~cm}$ to $18.20 \mathrm{~cm}$. Rashid (1999) reported that the length and width of hyacinth bean generally ranges $8-15 \mathrm{~cm}$ and $2.5-5.0 \mathrm{~cm}$, respectively. Heaviest fruit was obtained from LPPK013 (14.13 g) which was identical to LPPK012 (13.83 g) and LPPK002 (13.28 g) whereas, lowest single fruit weight was recorded from LPPK004 (5.085 g) which was identical to LPPK008 (5.38 g), IPSA Sheem 2 (5.58g), LPPK016 (5.63 g), LPPK017 (5.83 g) and LPPK005 (5.88 g). This might be inherent characteristics of the genotype. Maximum numbers of pods per plant were harvested from LPPK016 (1418.65) which were identical to LPPK005 (1249.9) and minimum numbers of pods per plant were harvested from LPPK003 (277.83) which were identical to LPPK002 (381.08), LPPK006 (445.9) and LPPK 010 (445.77). Our result was higher than Halim and Ahmed (1992) finding, in case of number of pods per plant and also ranged 180 to 330 among nine hyacinth bean lines. The variation in number of pods/plant might be due to differences in number of inflorescences/plant, pods/raceme, flower dropping tendency of the genotypes [11]. Maximum pod weight per plant (7.89 $\mathrm{kg}$ ) obtained from the line LPPK016 followed by BARI Sheem7 (7.87 kg), LPPK015 (7.73 kg), LPPK001 (7.42 kg) and LPPK011 (7.21 kg) and minimum in the line LPPK $003(2.29 \mathrm{~kg})$. The highest hundred seed weight ( $50.3 \mathrm{~g}$ ) was found from the line LPPK0011 and the lowest thousand seed weight (23.8 g) was obtained from the line LPPK008. BARI (2001) reported that the average weight of 100 seed was $41.99 \mathrm{~g}$ and ranged from 24.8 to $54.0 \mathrm{~g}$ [12], which extended slightly from the report of Rashid (1999) who reported that hundred seeds weight of country bean lies between $25-50 \mathrm{~g}$.

This higher/plant yield was attributed due to higher number of pods/plant. The highest yield obtained from the line LPPK016 (18.73 t/ha) and BARI Sheem7 (18.69 t/ha) closely followed by LPPK015 (18.35 t/ha), LPPK001 (17.62 t/ha) and LPPK011 (17.12 t/ha) and the lowest yield obtained in the line LPPK 003 (5.43 t/ha).

Lines found promising for five of the characters are shown in Table 2. LPPK001, LPPK002, LPPK012, LPPK014 and BARI Sheem 6 for pod-length; LPPK002, LPPK010, LPPK0012 for pod-breadth; LPPK 002, LPPK010, LPPK012 and LPPK 013 for high pod weight; LPPK 001, LPPK005, LPPK011, LPPK 015, LPPK016 and BARI Sheem 7 for high pod-number and LPPK001, LPPK005, LPPK0011, LPPK015, LPPK016 and BARI Sheem 7 for high pod-yield.

In our germplasm, different size and color of pods were found. Size and color of pods are important traits in deciding the marketability of a crop. All the genotypes evaluated had acceptable green pod color. Details for pod-colour are presented in Table 3. Variations were recorded for pod colour with four types, namely, green, light-green, purple- green, and creamy-white 15 were green in colour viz., BARI Sheem 1, BARI Sheem 6, BARI Sheem 7, LPPK002, LPPK003, LPPK004, LPPK005, LPPK006, LPPK007, LPPK008, LPPK009, LPPK010, LPPK0012, LPPK0013, LPPK015, LPPK016 and LPPK017 and IPSA Sheem 2 was light green, LPPK011 was purple green and LPPK001 and LPPK014 were creamy- white in colour. Variation in pod-colour was observed in dolichos germplasm collected by AVRDC in Bangladesh. Islam (2010) also reported 52.3\% were green color pod in his study [7-10].

The results indicated existence of wide variability for pod yield, pod length, pod breadth, pod weight, number of pods per plant and pod colour. Highyielding germplasm lines and lines with different pod-types can be utilized further in breeding programmes. Lines with colour variation can be used as phenotypic markers in genetic and hybridization studies.

Table 1: Yield and yield attributes of 17 country bean genotypes with check variety BARI Sheem-1, BARI Sheem-6, BARI Sheem-7 and IPSA Sheem 2 during 2017-18

\begin{tabular}{|c|c|c|c|c|c|c|c|c|c|c|c|}
\hline \multicolumn{2}{|c|}{ Line/Variety } & $\begin{array}{l}\text { Plant Height } \\
(\mathrm{cm}) \text { at } 60 \\
\text { days }\end{array}$ & $\begin{array}{l}\text { No. of } \\
\text { primary } \\
\text { branches }\end{array}$ & $\begin{array}{l}\text { Days to } \\
\text { first } \\
\text { harvest }\end{array}$ & $\begin{array}{l}\text { Pod } \\
\text { length } \\
\text { (cm) } \\
\end{array}$ & $\begin{array}{l}\text { Pod } \\
\text { breadth } \\
\text { (cm) }\end{array}$ & $\begin{array}{l}\text { Pod } \\
\text { weight } \\
\text { (gm) } \\
\end{array}$ & $\begin{array}{l}\text { No. of } \\
\text { pods/plant }\end{array}$ & $\begin{array}{l}\text { Yield/plant } \\
\text { (kg) }\end{array}$ & $\begin{array}{l}\text { 100-seed } \\
\text { weight }\end{array}$ & $\begin{array}{l}\text { Yield } \\
\text { (t/ha) }\end{array}$ \\
\hline \multicolumn{2}{|c|}{ LPPK 001} & 295.25 b-d & $5.26 \mathrm{~b}-\mathrm{d}$ & $113.6 \mathrm{~b}-\mathrm{d}$ & $15.34 \mathrm{~b}$ & $2.11 \mathrm{hi}$ & $6.78 \mathrm{hi}$ & $1097.83 \mathrm{bc}$ & $7.42 \mathrm{ab}$ & $40.05 \mathrm{~b}$ & $17.62 \mathrm{ab}$ \\
\hline \multicolumn{2}{|c|}{ LPРК002 } & $205.25 \mathrm{f}$ & $8.26 \mathrm{a}$ & $117.6 \mathrm{~b}-\mathrm{d}$ & $15.25 \mathrm{bc}$ & $4.21 \mathrm{~b}$ & $13.28 \mathrm{a}$ & $381.08 \mathrm{ij}$ & $5.27 \mathrm{c}-\mathrm{e}$ & $32.05 \mathrm{~d}$ & $12.51 \mathrm{c}-\mathrm{e}$ \\
\hline \multicolumn{2}{|c|}{ LPPK003 } & $295.25 b-d$ & $3.26 \mathrm{~g}$ & $127.6 \mathrm{a}-\mathrm{c}$ & $12.74 \mathrm{~d}$ & $3.31 \mathrm{~cd}$ & $8.48 \mathrm{de}$ & $277.83 \mathrm{j}$ & $2.29 \mathrm{~h}$ & $32.05 \mathrm{~d}$ & $5.43 \mathrm{~h}$ \\
\hline \multicolumn{2}{|c|}{ LPPK004 } & $265.25 \mathrm{c}-\mathrm{f}$ & $5.26 \mathrm{~b}-\mathrm{d}$ & $131.6 \mathrm{ab}$ & 8.74 h-k & $1.41 \mathrm{j}$ & $5.08 \mathrm{k}$ & $914.58 \mathrm{~cd}$ & $4.50 \mathrm{ef}$ & $28.05 \mathrm{e}$ & $10.68 \mathrm{ef}$ \\
\hline \multicolumn{2}{|c|}{ LPPK005 } & 327.75 a-c & $3.56 \mathrm{~g}$ & $140.35 \mathrm{a}$ & $9.37 \mathrm{~g}-\mathrm{j}$ & $2.41 \mathrm{f}-\mathrm{h}$ & $5.88 \mathrm{i}-\mathrm{k}$ & $1249.9 \mathrm{ab}$ & $7.31 \mathrm{ab}$ & $31.8 \mathrm{~d}$ & $17.36 \mathrm{ab}$ \\
\hline \multicolumn{2}{|c|}{ LPPK006 } & 277.75 c-e & $4.56 \mathrm{~d}-\mathrm{f}$ & 129.35 a-c & $13.37 \mathrm{~cd}$ & $3.51 \mathrm{c}$ & $9.98 \mathrm{c}$ & $445.9 \mathrm{ij}$ & $4.36 \mathrm{e}-\mathrm{g}$ & $27.8 \mathrm{e}$ & $10.35 \mathrm{e}-\mathrm{g}$ \\
\hline \multicolumn{2}{|c|}{ LPPK007 } & $272.75 \mathrm{c}-\mathrm{f}$ & $8.56 \mathrm{a}$ & $131.35 \mathrm{ab}$ & $12.17 \mathrm{de}$ & $3.31 \mathrm{~cd}$ & $7.98 \mathrm{ef}$ & $776.9 \mathrm{~d}-\mathrm{f}$ & 6.15 b-d & $27.8 \mathrm{e}$ & $14.60 \mathrm{~b}-\mathrm{d}$ \\
\hline \multicolumn{2}{|c|}{ LPPK008 } & 287.75 c-e & $4.56 \mathrm{~d}-\mathrm{f}$ & $106.35 \mathrm{de}$ & $8.47 \mathrm{i}-\mathrm{k}$ & $1.51 \mathrm{j}$ & $5.385 \mathrm{k}$ & $955.65 \mathrm{~cd}$ & $5.15 \mathrm{de}$ & $23.8 \mathrm{f}$ & $12.23 \mathrm{de}$ \\
\hline \multicolumn{2}{|c|}{ LPРК009 } & $302.75 \mathrm{~b}-\mathrm{d}$ & $5.885 \mathrm{bc}$ & $140.85 \mathrm{a}$ & $7.62 \mathrm{k}$ & $2.46 \mathrm{fg}$ & $7.36 \mathrm{f}-\mathrm{h}$ & $819.27 \mathrm{de}$ & $6.30 \mathrm{a}-\mathrm{d}$ & $36.3 \mathrm{c}$ & $14.96 \mathrm{a}-\mathrm{d}$ \\
\hline \multicolumn{2}{|c|}{ LPPK010 } & 277.75 c-e & $5.885 \mathrm{bc}$ & 126.85 a-c & $13.32 \mathrm{~cd}$ & $3.96 \mathrm{~b}$ & $11.66 \mathrm{~b}$ & $445.77 \mathrm{ij}$ & $5.57 \mathrm{c}-\mathrm{e}$ & $32.3 d$ & $13.22 \mathrm{c}-\mathrm{e}$ \\
\hline \multicolumn{2}{|c|}{ LPPK011 } & $217.75 \mathrm{ef}$ & $3.885 \mathrm{fg}$ & $131.85 \mathrm{ab}$ & $10.22 \mathrm{f}-\mathrm{h}$ & $2.16 \mathrm{hi}$ & $6.56 \mathrm{~h}-\mathrm{j}$ & $1062.02 \mathrm{bc}$ & $7.21 \mathrm{ab}$ & $50.3 \mathrm{a}$ & $17.12 \mathrm{ab}$ \\
\hline \multicolumn{2}{|c|}{ LPPK012 } & 395.25 a & $4.16 \mathrm{fg}$ & $112.35 \mathrm{c}-\mathrm{e}$ & $15.07 \mathrm{~b}$ & $4.83 \mathrm{a}$ & $13.83 \mathrm{a}$ & $512.83 \mathrm{hi}$ & $6.79 \mathrm{a}-\mathrm{c}$ & $32.3 \mathrm{~d}$ & $16.12 \mathrm{a}-\mathrm{c}$ \\
\hline \multicolumn{2}{|c|}{ LPPK013 } & 295.25 b-d & $6.16 \mathrm{~b}$ & 119.35 b-d & $13.17 \mathrm{~cd}$ & $3.23 \mathrm{~cd}$ & $14.13 a$ & $501.33 \mathrm{hi}$ & $6.79 \mathrm{a}-\mathrm{c}$ & $32.3 \mathrm{~d}$ & 16.12 a-c \\
\hline \multicolumn{2}{|c|}{ LPPK014 } & 280.25 c-e & $4.16 \mathrm{fg}$ & 109.35 de & $15.67 \mathrm{~b}$ & $2.25 \mathrm{gh}$ & $9.43 \mathrm{~cd}$ & $736.08 \mathrm{~d}-\mathrm{g}$ & $6.76 \mathrm{a}-\mathrm{c}$ & $36.3 \mathrm{c}$ & $16.05 \mathrm{a}-\mathrm{c}$ \\
\hline \multicolumn{2}{|c|}{ LPPK015 } & $364 \mathrm{ab}$ & $9.135 \mathrm{a}$ & $131.85 \mathrm{ab}$ & $11.09 \mathrm{ef}$ & $2.28 \mathrm{gh}$ & $6.93 \mathrm{gh}$ & $1131.4 \mathrm{bc}$ & $7.73 \mathrm{ab}$ & $41.55 \mathrm{~b}$ & $18.35 \mathrm{ab}$ \\
\hline \multicolumn{2}{|c|}{ LPPK016 } & $239 \mathrm{~d}-\mathrm{f}$ & $6.135 \mathrm{~b}$ & 128.85 a-c & $9.49 \mathrm{~g}-\mathrm{j}$ & $1.55 \mathrm{j}$ & $5.63 \mathrm{jk}$ & $1418.65 \mathrm{a}$ & $7.89 \mathrm{a}$ & $39.55 \mathrm{~b}$ & $18.73 \mathrm{a}$ \\
\hline \multicolumn{2}{|c|}{ LPPK017 } & $264 \mathrm{c}-\mathrm{f}$ & 5.135 c-e & 129.85 a-c & $9.89 \mathrm{f}-\mathrm{i}$ & $2.88 \mathrm{e}$ & $5.83 \mathrm{i}-\mathrm{k}$ & $549.65 \mathrm{~g}-\mathrm{i}$ & $3.28 \mathrm{f}-\mathrm{h}$ & $31.55 \mathrm{~d}$ & $7.79 \mathrm{f}-\mathrm{h}$ \\
\hline \multicolumn{2}{|c|}{ BARI Sheem 1} & $293 \mathrm{~cd}$ & $4.44 \mathrm{ef}$ & $98.6 \mathrm{e}$ & $11.5 \mathrm{e}$ & $2.58 \mathrm{f}$ & $9.58 \mathrm{c}$ & 713.5 e-g & $6.89 \mathrm{ab}$ & $28.2 \mathrm{e}$ & $16.36 \mathrm{~b}$ \\
\hline \multicolumn{2}{|c|}{ BARI Sheem 6} & $264 \mathrm{~d}-\mathrm{f}$ & $6.08 \mathrm{~b}$ & $110.2 \mathrm{de}$ & $20.4 \mathrm{a}$ & $2 \mathrm{i}$ & $6.82 \mathrm{~h}$ & $866.3 \mathrm{~d}$ & $5.92 \mathrm{~cd}$ & $35.8 \mathrm{c}$ & $14.06 \mathrm{~cd}$ \\
\hline \multicolumn{2}{|c|}{ BARI Sheem 7} & $282 \mathrm{c}-\mathrm{e}$ & $6.16 \mathrm{~b}$ & $68.8 \mathrm{f}$ & $10.32 \mathrm{fg}$ & $3.22 \mathrm{~d}$ & $7.46 \mathrm{fg}$ & $1056.45 \mathrm{c}$ & $7.87 \mathrm{a}$ & $28.4 \mathrm{e}$ & $18.69 \mathrm{a}$ \\
\hline \multicolumn{2}{|c|}{ IPSA Sheem 2} & 237 ef & $4.36 \mathrm{f}$ & $106.8 \mathrm{de}$ & $8.46 \mathrm{jk}$ & $2.24 \mathrm{gh}$ & $5.58 \mathrm{k}$ & $616.6 \mathrm{f}-\mathrm{h}$ & $3.22 \mathrm{gh}$ & $31.8 \mathrm{~d}$ & $7.64 \mathrm{gh}$ \\
\hline \multirow{2}{*}{ L.S. } & $\begin{array}{l}\text { Treatment } \\
\text { adjusted }\end{array}$ & $* *$ & $*$ & $* *$ & $* *$ & $* *$ & $* *$ & $* *$ & $* *$ & $* *$ & $* *$ \\
\hline & $\begin{array}{l}\text { Block } \\
\text { adjusted }\end{array}$ & $* *$ & NS & NS & NS & NS & NS & NS & NS & NS & NS \\
\hline
\end{tabular}


Table 2: Grouping of hyacinth bean germplasm for yield and pod related traits

\begin{tabular}{|l|l|c|}
\hline Traits & Lines /Variety & No. of lines \\
\hline Pod length $(>15 \mathrm{~cm})$ & BARI Sheem 6, LPPK001, LPPK002, LPPK012, LPPK014 & 5 \\
\hline Pod breadth $(>3.5 \mathrm{~cm})$ & LPPK002, LPPK010 and LPPK0012 & 3 \\
\hline Pod weight $(>10 \mathrm{~g})$ & LPPK 002, LPPK010, LPPK012 and LPPK 013 & 4 \\
\hline Number of pod per plant $(>1000)$ & LPPK 001, LPPK005, LPPK011, LPPK 015, LPPK016 and BARI Sheem 7 & 6 \\
\hline Pod yield per plant $(>7 \mathrm{~kg})$ & LPPK001, LPPK005, LPPK0011, LPPK015, LPPK016 and BARI Sheem 7 & 6 \\
\hline
\end{tabular}

Table 3: Grouping of hyacinth bean germplasm on the basis of pod colour

\begin{tabular}{|l|l|c|}
\hline Pod colour & Germplasm & No. of Lines \\
\hline Green & $\begin{array}{l}\text { BARI Sheem 1, BARI Sheem 6, BARI Sheem 7, LPPK002, LPPK003, LPPK004, LPPK005, LPPK006, } \\
\text { LPPK007, LPPK008, LPPK009, LPPK010, LPPK0011, LPPK0012, LPPK0013, LPPK015, LPPK016 } \\
\text { and LPPK017 }\end{array}$ & 15 \\
\hline Light green & IPSA Sheem 2 & 1 \\
\hline Purple green & LPPK011 & 1 \\
\hline Creamy-white & LPPK001 and LPPK014 & 2 \\
\hline
\end{tabular}

\subsection{Conclusions}

The study revealed that for considering higher yield of five lines, LPPK001, LPPK005, LPPK0011, LPPK015, LPPK016 were found promising. Besides, LPPK002, LPPK010 and LPPK0012 were for wider breadth and LPPK001 and LPPK014 were for creamy -white pod colour was also selected. It is the first year study, so the trial will be repeated with more lines for conclusive result.

\subsection{References}

[1] M. Rashid, “Legume Vegetables. Shabji Bigyan (in Bengali)”. 2nd ed. Rashid Publishing House. 94, Old DOHS, Dhaka-1206. pp 370-409. 1999.

[2] J.B Morris. "Bio-Functional Legumes With Nutraceutical, Pharmaceutical And Industrial Uses". Econ. Bot. 57: 254-261. 2003.

[3] M. Naeem, Masroor M., Khan A., Morris J.B. "Agrobotanical Attrib-utes, Nitrogen-Fixation, Enzyme Ac-Tivities And Nutraceuticals Of Hya-Cinth Bean (Lablab Purpureus L.): A Bio-Functional Medicinal Legume”. Amer. J. Plant Physiol. 4: 58-69. 2009b.

[4] J.B Morris. "Morphological and Reproductive Characterization In Hy-Acinth Bean, Lablab Purpureus (L.) Sweet Germplasm With Clinically Proven Nutraceutical And Pharma-Ceutical Traits For Use As A Medicinal Food". Journal of Dietary Supple-ments 6 (3): 263-279. 2009.

[5] T., Islam, M. M. Haque and M. M. Rahman. “Catalouge on hyacinth bean germplasm”. PGRC, BARI, Gazipur. pp. 55. 2002.

[6] M. S., Islam, M. M. Rahman and T. Hossain. "Physico-morphological variation in hyacinth bean [Lablab Purpureus (L.) Sweet]”. Bangladesh J Agril. Res. 35(3): 431-438. 2010.

[7] Anonymous. "Annual Report”, AVRDC, World Vegetable Center, Tainan, Taiwan, p. 82, 2000.

[8] B.C.S., Jagadeesh, Byregowda, M. and Girish, G. "Screening of Dolichos Germplasm For Pod Borers And Bruchids". Environmental Ecology, 26(4): 2288-2290. 2008.

[9] A., Regupathy, Palaniswamy, G.A. and Krishnan, R.H. "Assessment of loss in seed yield by pod borers in certain varieties of field bean". Madras Agricultural Journal, 57(5): 274-8. 1970.

[10] P. A., Sofi, Zargar, M. Y., Debouck, D., \& Graner, A. “Evaluation of Common Bean (Phaseolus Vulgaris L) Germplasm Under Temperate Conditions of Kashmir Valley". Journal of Phytology, 3(8), 47-5. 2011.

[11] BARI. "Characterization and variability in hyacinth bean germplasms grown at the hilly areas of Bangladesh". Annual Report, 2001.

[12] M. M. R. Khan, "Performance of Lablab Bean Genotypes Under Different Supports". M.S. Thesis, Department of Horticulture, BSMRAU, Salna, Gazipur76p. 2003. 